\title{
ZARZĄDZANIE OPARTE NA WSPÓŁPRACY I ZAUFANIU. ANALIZA NA PRZYKŁADZIE ŚRODOWISKA ZAWODOWEGO POLICJANTÓW
}

\author{
Monika Żak \\ Uniwersytet Śląski w Katowicach \\ Wydział Nauk Społecznych
}

\begin{abstract}
Streszczenie: Służba w policji należy do tzw. zawodów wysokiego ryzyka, a jej wykonywanie wiąże się z koniecznością dostosowania do specyficznych warunków pracy. Trudność zadań zawodowych policjantów oraz ich znaczenie dla funkcjonowania społeczeństwa sprawia, że niezbędna staje się dobra współpraca oraz zaufanie do partnerów służbowych. Zaufanie to dotyczy nie tylko najbliższych współpracowników, ale również zaufania do przełożonych oraz misji całej formacji. Uzyskanie takiego stanu rzeczy jest możliwe dzięki właściwemu zarządzaniu formacją i kształtowaniu odpowiedniej kultury organizacyjnej. Celem artykułu jest prezentacja i analiza fragmentu wyników badań przeprowadzonych wśród funkcjonariuszy policji m.in. na temat znaczenia zaufania i współpracy w realizacji ich obowiązków zawodowych. Analiza ta ma charakter studium przypadku, a podstawą opracowania stały się informacje pozyskane w drodze wywiadów przeprowadzonych z policjantami z całej Polski w ramach większego projektu badawczego mającego na celu określenie specyfiki służby w policji i jej wpływu na życie pozazawodowe.
\end{abstract}

Słowa kluczowe: policja, współpraca, zarządzanie, zaufanie, zawód wysokiego ryzyka

DOI: $10.17512 /$ znpcz.2018.1.04

\section{Wprowadzenie}

Realizacja wielu obowiązków służbowych wiąże się z koniecznością współpracy i zaufania zarówno w stosunku do współpracowników, jak i partnerów biznesowych. Relacje międzyludzkie, które mają prowadzić do osiągnięcia zamierzonych celów, realizacji przyjętych zadań, muszą być oparte na zaufaniu. Zaufanie jest procesem złożonym, zależnym od wielu czynników. Zależy od doświadczeń z drugą osobą lub organizacją. Ponadto jest procesem rozłożonym w czasie (Rudzewicz 2016, s. 16). W przypadku niektórych profesji znaczenie zaufania oraz współpracy jest szczególnie istotne. W zawodach wysokiego ryzyka zaufanie jest podstawą działania, a efektywne działanie nie jest możliwe bez współpracy wszystkich zaangażowanych osób. Ludzie stanowią podstawę funkcjonowania organizacji i zdecydowanie zwiększają jej efektywność (Adamiec, Kożusznik 2000, s. 16). Współcześnie kładzie się nacisk na znaczenie zaufania $w$ relacjach międzyludzkich. Jest to spowodowane wzrostem liczby zagrożeń i sytuacji niepewności, jakie towarzyszą ludziom każdego dnia (Żółkowska 2014, s. 235). Policjanci, strażacy czy żołnierze swoje zadania służbowe realizują w duchu ścisłej współpracy, a u jej podstaw leży 
wysoki poziom wzajemnego zaufania. W tego typu zawodach nie może być miejsca na brak zaufania czy też działanie indywidualne, ponieważ zarówno specyfika zadań, jak też ich ogólnospołeczny charakter determinują sposób działania. Ważnym zatem wydaje się odpowiednie zarządzanie, które będzie skutkowało realizacją obowiązków opartych na wzajemnym zaufaniu i współpracy. Rola kierowników, przełożonych w zarządzaniu policjantami wydaje się być w tym przypadku kluczowa i wymaga od nich posiadania odpowiednich kompetencji i zaangażowania $\mathrm{w}$ pracę. Zarządzanie koncentruje się $\mathrm{w}$ dużej mierze na realizacji bieżących zadań, planowaniu i wykluczaniu potencjalnego ryzyka w organizacji. Niezbędne jest tu również adekwatne motywowanie, a także minimalny, acz niezbędny nadzór i kontrola (Krupski 2004, s. 35, za: Gliński 1996, s. 37). W niniejszym artykule zaprezentowany zostanie fragment wyników badań, jakie przeprowadzono wśród przedstawicieli zawodów wysokiego ryzyka - policjantów. Całość opracowania oparto o przyjęte założenia teoretyczne. Ujęcie definicyjne i koncepcje zaufania zostaną zaprezentowane $\mathrm{w}$ pierwszej części artykułu. W następnej zaś przedstawione będą wyniki badań własnych autorki. Prezentowane wyniki są fragmentem większego projektu badawczego, którego celem było określenie miejsca służby $\mathrm{w}$ życiu funkcjonariuszy policji. Jednym $\mathrm{z}$ elementów poddanych badaniu były opinie policjantów na temat współpracy i specyfiki służby w kwestii zaufania, a w szczególności zaś zaufania, które staje się podstawą relacji pozasłużbowych, przyjacielskich.

\section{Zaufanie i współpraca w zarządzaniu - ujęcie teoretyczne}

Kwestię zaufania i współpracy można rozpatrywać w kontekście praktycznie każdej profesji, nawet w odniesieniu do tzw. wolnych zawodów. Niemniej jednak wydaje się szczególnie istotne badanie tych aspektów w przypadku przedstawicieli zawodów wysokiego ryzyka. „Zaufanie jest faktem społecznym, który istotny staje się tylko w szczególnych sytuacjach, w których trzeba się zaangażować w sytuacje niemożliwe do uprzedniego skontrolowania" (Luhmann 2007, s. 124). Obowiązki służbowe przedstawicieli tych profesji mają specyficzny charakter i wpływają na sprawne funkcjonowanie całego społeczeństwa, stąd nie jest możliwe swobodne i indywidualne interpretowanie przydzielonych zadań i przepisów regulujących ich wykonywanie. Wiąże się to również z faktem, że w wielu przypadkach tego typu profesji istnieje bardzo silna hierarchia i zależność służbowa, co również wpływa na konieczność daleko idącego zaufania i współpracy. W polskiej policji zdecydowana większość przepisów, regulaminów, zasad i zaleceń dotyczących sposobów i form realizacji zadań służbowych zakłada ścisłą współpracę zarówno między poszczególnymi funkcjonariuszami, jak i różnymi jednostkami w ramach struktury organizacyjnej. Współpraca opiera się tutaj na formalnie ustanowionych prawach i zasadach, lecz równie ważne są relacje, które nie mają charakteru sformalizowanego, ale stanowią wynik codziennej aktywności zawodowej i realizacji wspólnych zadań (Peszko 2002, s. 62). W przypadku policjantów ta nieformalna część pracy dotyczy w głównej mierze kształtowania się zaufania wzajemnego jako podstawy efektywnej współpracy. Badaniem znaczenia współpracy, współdziałania zajmo- 
wali się już starożytni myśliciele (np. Platon i Arystoteles podkreślali znaczenie współdziałania jako podstawy sprawnego funkcjonowania organizmu państwowego). Analiza współpracy nie jest więc wytworem naszych czasów, a bogaty dorobek naukowy w tym zakresie tylko to potwierdza. Dzisiaj najczęściej analizuje się zaufanie jako element kapitału społecznego. Zdaniem Francisa Fukuyamy kapitał społeczny, którego elementem jest zaufanie, wpływa na charakter gospodarki i zmniejsza koszty prowadzenia interesów (Fukuyama 1997, s. 40). Kapitał społeczny, jakiego częścią jest zaufanie, stanowi podstawę sprawnego funkcjonowania nie tylko organizacji, miejsc pracy, ale również, a może przede wszystkim, całych społeczeństw, ponieważ stanowi zespół formalnych i nieformalnych powiązań umożliwiających efektywne zarządzanie i działanie w ramach organizacji (Mika 2009, s. 40).

Funkcjonowanie poszczególnych grup zawodowych jest oparte na szeroko rozumianym kapitale społecznym. W przypadku niektórych zawodów wysokiego ryzyka można również mówić jako o zawodach zaufania społecznego, co wskazuje na ich znaczenie dla społecznego funkcjonowania. Zaufanie do przedstawicieli tych profesji jest warunkiem niezbędnym dla ich istnienia. Na początku należy jednak uściślić, w jaki sposób będzie określany zawód wysokiego ryzyka. Na potrzeby realizowanego projektu badawczego przyjęto następującą definicję: Zawód wysokiego ryzyka to wykonywanie określonych czynności, które wynikaja ze spotecznego podzialu pracy $i$ sa istotne dla funkcjonowania catego spoteczeństwa. Owe czynności wymagaja od osoby je wykonujacej wykazania się określonymi cechami zarówno natury fizycznej, jak i odpowiednimi predyspozycjami psychicznymi, a także wysokim stopniem profesjonalizacji $i$ wiedzy. Wykonywanie tego typu zawodu wiąze się z podejmowaniem ryzyka, działaniem $w$ sytuacjach niebezpiecznych $i$ warunkach trudnych, stresogennych, wreszcie z narazaniem własnego zdrowia, a nawet życia. Czynności zawodowe maja tutaj istotne znaczenie dla egzystencji całego społeczeństwa, gdyż umożliwiaja jego sprawne funkcjonowanie, a także niosa pomoc wszystkim jego członkom w sytuacjach, które tego wymagaja. Powyższe ujęcie ma charakter dosyć szczegółowy, ale autorce zależało na tym, by odróżnić pojęcie zawodu wysokiego ryzyka, jakie funkcjonuje w społecznej (zgodnej z koncepcją autorki) świadomości, od innych profesji, które choć również mogą być niebezpieczne, nie są obarczone aż tyloma wymogami (np. specjaliści zajmujący się myciem i konserwacją okien i fasad w wieżowcach). „Do grupy zawodów trudnych i niebezpiecznych zalicza się m.in. zawód strażaka, pilota, górnika, kierowcy, ratownika górskiego czy policjanta" (Lubrańska 2008, s. 19).

Analiza zaufania i współpracy powinna być zawsze dokonywana w odniesieniu do konkretnych profesji, ponieważ duże znaczenie ma tutaj specyfika zawodu. W przypadku służby w policji zaufanie i współpraca mają kluczowe znaczenie, zarówno dla samych policjantów, jak i wszystkich beneficjentów ich służby. Należy zauważyć, że choć jest ono niemalże wpisane w definicję tej służby, to zasadnicza wydaje się być tutaj przyjęta strategia zarządzania na każdym poziomie organizacji. Z głównych elementów przyjmowanej polityki zarządzania kadrami czynniki otoczenia, czynniki sytuacyjne, technologia, wpływ otoczenia zewnętrznego (Armstrong 2000, s. 30) - w przypadku policjantów do najważniejszych nale- 
żą czynniki sytuacyjne oraz czynniki otoczenia. To charakter służby, rola policji jako organizacji (czynniki sytuacyjne) oraz relacje między poszczególnymi funkcjonariuszami decydują o budowaniu zaufania, a na jego bazie - o skutecznej współpracy.

Samo pojęcie zaufania jest bardzo wieloznaczne i wieloaspektowe, można je analizować w kontekście indywidualnym, społecznym, organizacyjnym, intraorganizacyjnym, międzyorganizacyjnym etc. Jego jednoznaczne zdefiniowanie jest w tej sytuacji bardzo trudne, a tłumaczenie poszczególnych zagadnień (w szczególności w ramach nauk społecznych) ma charakter permanentny (Babbie 2008, s. 150). W literaturze można spotkać bardzo wiele propozycji ujęcia zaufania. W tym miejscu przytoczonych zostanie tylko kilka, które - w opinii autorki oraz w kontekście podejmowanego problemu - najtrafniej oddają koncepcję zaufania. Zdaniem Marka Bugdola: „Zaufanie to coś, co zostało stworzone w organizacji dla ludzi i przez ludzi, a oparte jest na pewnym poziomie przewidywalności (skutków i konsekwencji)" (Bugdol 2006, s. 22). Ten sam autor wskazuje, że zaufanie skutkuje przeświadczeniem, że podejmowana aktywność może doprowadzić do realizacji zamierzonych celów i być źródłem korzyści dla wszystkich zainteresowanych stron (Bugdol 2010, s. 16). Mamy tutaj do czynienia z postrzeganiem zaufania jako warunku determinującego efektywne działania, które doprowadzą do osiągnięcia zamierzonego w procesie pracy celu. $\mathrm{W}$ odniesieniu do policjantów takie definiowanie zaufania jest jak najbardziej adekwatne. Nieco inaczej kwestię zaufania definiuje Annette Baier, która twierdzi, że zaufanie to skłonność do polegania na innych i chęci opieki aniżeli wyrządzania szkody w zadaniu, którego się podjęto (Baier 1986, s. 259). Przywołana autorka zdaje się doskonale wpisywać w rolę i misję policjantów, dla których dobro społeczne powinno być najwyższą wartością, a zaufanie ma tutaj dwojakie znaczenie: zaufanie między funkcjonariuszami oraz zaufanie społeczeństwa do funkcjonariuszy. Podobnie - bardzo trafnie w kontekście funkcjonowania zaufania do policji - podchodzą Stephen C. Currall i Timothy A. Judge, którzy twierdzą, że jest to poleganie jednostki na innej osobie w sytuacji zagrożenia (Currall, Judge 1995, s. 151). Bernard Barber określa zaufanie za pomocą trzech rodzajów oczekiwań:

- oczekiwanie, że porządek społeczny zostanie utrzymany;

- oczekiwanie dotyczące kompetentnego wykonywania roli społecznych przez wszystkich członków społeczeństwa;

- oczekiwanie, że partner w relacji będzie odpowiedzialny (Barber 1983).

$\mathrm{W}$ tym duchu swoją definicję zaufania proponuje również Joanna Paliszkiewicz, zdaniem której „Zaufanie do kogoś lub czegoś wiąże się zatem z przekonaniem, że druga strona (ktoś lub coś) nie będzie działała przeciwko nam. Im silniejsze jest to przekonanie, tym większa gotowość do współpracy, ponieważ większe jest subiektywne prawdopodobieństwo powodzenia" (Paliszkiewicz 2013, s. 23).

Ostatnia przytoczona definicja podnosi kwestię współpracy, która dla analizy sytuacji zawodowej policjantów wydaje się być kluczowa. Zaufanie jest pierwszym i podstawowym warunkiem pełnienia służby w policji. Funkcjonariusze muszą wierzyć i ufać w misję, której się podjęli, wstępując w szeregi tej formacji, muszą oni również ufać, że ich współpracownicy podchodzą do swoich zadań w równie 
rzetelny i oddany sposób. Takiego podejścia adepci służby w policji uczą się już w trakcie kursu podstawowego, kiedy poznają specyfikę swojej profesji. Współpraca stanowi podstawowy warunek powodzenia i efektywnego funkcjonowania policji. Indywidualne podejście do obowiązków lub, co gorsze, współzawodnictwo, nie mają prawa zaistnieć - przyniosłoby to bowiem negatywne skutki zarówno dla działających w ten sposób policjantów, jak i dla całej organizacji. Rola zarządzających jest tutaj uzależniona od sytuacji i aktualnych potrzeb:

- role reaktywne/proaktywne - kierownictwo policji w głównej mierze kształtuje i podtrzymuje właściwe postawy podwładnych oparte na zaufaniu i współpracy - działania proaktywne. Przełożeni muszą jednak również reagować w sytuacji, gdy wystąpią problemy z zaufaniem lub współpracą - działania reaktywne, do których należą:

- rola partnera - sprowadza się ona do faktu, że wszystkim funkcjonariuszom, niezależnie od stopnia służbowego i pełnionej funkcji, przyświeca jeden cel, jakim jest służba dla bezpieczeństwa i dobra społecznego;

- rola stratega - przełożeni muszą przewidywać ewentualne problemy związane z budowaniem zaufania i współpracą oraz przedsięwziąć odpowiednie środki zaradcze;

- rola interwencjonisty - sprowadza się do szybkich i doraźnych działań, które mają na celu zażegnanie problemu braku zaufania i/lub braku współpracy między policjantami;

- rola innowatora - wprowadzanie nowych rozwiązań, których celem jest usprawnienie działania podległej jednostki poprzez budowanie atmosfery zaufania i współdziałania;

- rola wewnętrznego konsultanta - dzielnie się doświadczeniami i dobrymi praktykami z innymi zarządzającymi;

- rola monitorującego - sprawdza, czy przyjęte zasady formalne i nieformalne są przestrzegane (por.: Armstrong 2000, s. 37-41).

Współpraca, którą w tym miejscu możemy zamiennie nazywać współdziałaniem, jest jedną z form interakcji społecznych i bardzo często jest rozpatrywana w opozycji do pojęcia konfliktu. Współdziałanie nie stanowi li tylko podłoża licznych refleksji teoretycznych, ale jest również elementem funkcjonowania organizacji opartych na podziale pracy (Misztal 1977, s. 157). Współdziałanie oparte na zaufaniu jest podstawą sprawnego funkcjonowania zespołu pracowników, co w sposób oczywisty przekłada się na efektywność organizacji i realizację jej misji. „Jedynie $\mathrm{w}$ sporadycznych przypadkach proces pracy przebiega indywidualnie. Zazwyczaj ludzie pracują zespołowo, mamy więc do czynienia ze zjawiskami pracy zespołowej. Miejscem pracy zespołowej jest przedsiębiorstwo, zwane ogólnie zakładem pracy lub firmą [...]. Przedsiębiorstwo jest organizmem społecznym, a każdy organizm społeczny żyje swoim własnym (wewnętrznym) życiem [...]. Organizacja ma ogromny wpływ na zachowania pracownicze, a także na przebieg integracji zespołu pracowniczego" (Milian 2002, s. 6-7). O roli zaufania w tworzeniu sprawnej współpracy można mówić w dwojaki sposób: to zaufanie determinuje współpracę, ale również - zdaniem Piotra Sztompki - najbardziej złożone formy 
zaufania tworzą się, gdy dochodzi do współpracy, a jednostkowe działanie nie pozwoli na osiągnięcie zamierzonego celu (Sztompka 2007, s. 138).

Zaufanie warunkuje współpracę, ale również współdziałanie jest czynnikiem sprzyjającym tworzeniu się zaufania. Tworzenie zaufania między pracownikami i wobec organizacji stanowi warunek sine qua non sprawnego i efektywnego jej funkcjonowania zarówno $\mathrm{w}$ wymiarze wewnętrznym, jak i ze środowiskiem zewnętrznym. Na Rysunku 1 zobrazowano, jakie czynniki mają wpływ na poziom zaufania w organizacji.

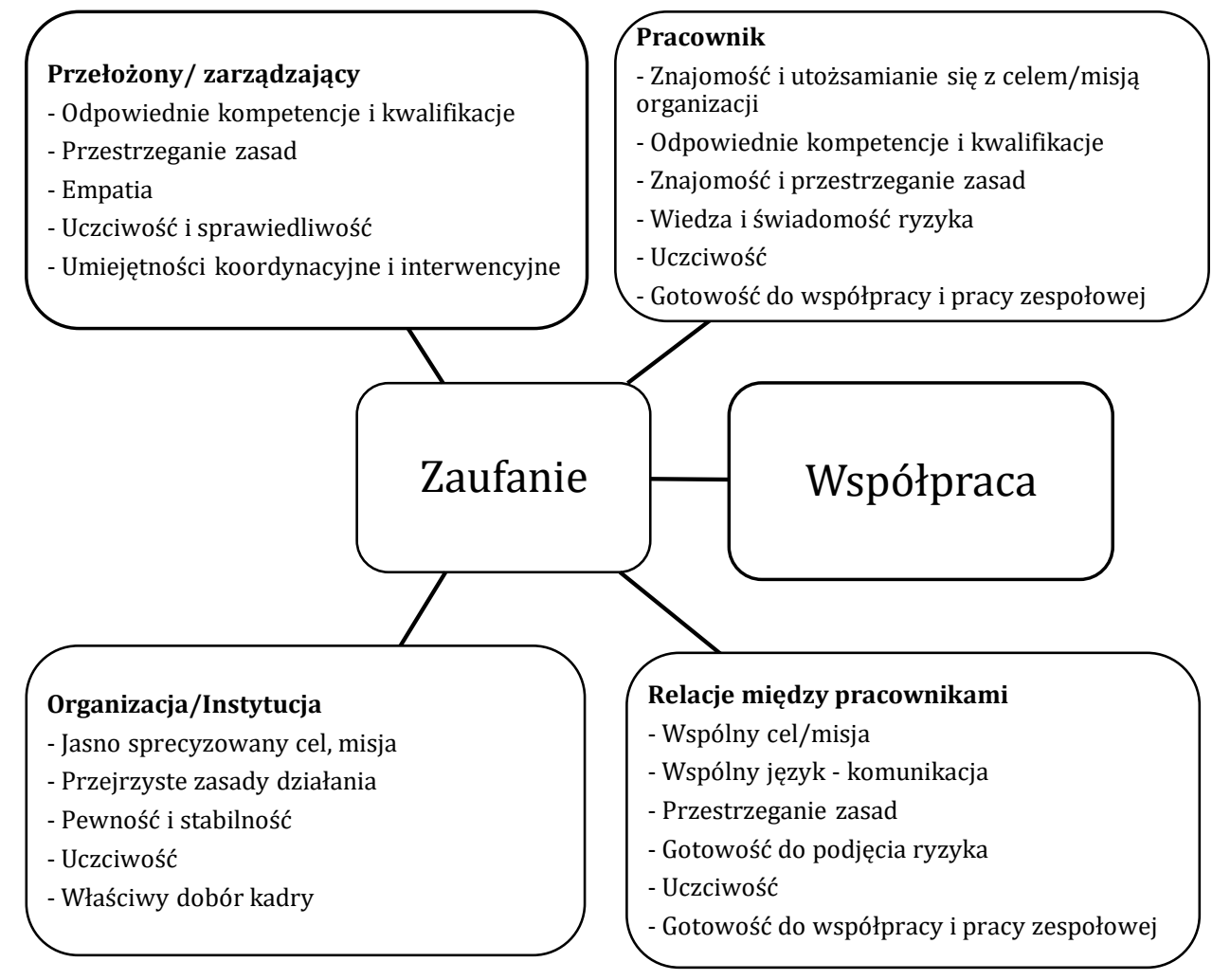

\section{Rysunek 1. Model zaufania wewnątrz- i międzyorganizacyjnego}

Źródło: Opracowanie własne

Wysoki poziom zaufania społecznego i jego szczególnej formy, zaufania zawodowego, sprzyja bardziej efektywnej działalności i stanowi korzyść zarówno dla pracowników, jak i odbiorców efektów ich pracy. Wysoki poziom zaufania gwarantuje większą efektywność funkcjonowania i działania organizacji (Tittenbrun 2006, s. 44). Delegowanie obowiązków na szczeble niższe jest szczególnie widoczne w przypadku zhierarchizowanych instytucji, gdzie również kwestia odpowiedzialności jest ściśle określona. Policja jako taka organizacja opiera się na delegowaniu obowiązków, a współpraca między policjantami oparta jest na zaufaniu. 
W dalszej części artykułu zaprezentowane zostaną wyniki badań przeprowadzonych wśród funkcjonariuszy w kontekście współpracy i zaufania w ich służbie.

\section{Zaufanie i współpraca jako podstawa działań funkcjonariuszy policji}

Wyniki badań, jakie zostaną zaprezentowane poniżej, są częścią większego projektu badawczego. Badania zostały przeprowadzone wśród funkcjonariuszy policji z całej Polski. Wśród respondentów znaleźli się policjanci będący uczestnikami kursów specjalistycznych prowadzonych przez Szkołę Policji w Pile. Na pytania zawarte $\mathrm{w}$ kwestionariuszu ankiety oraz pytania zadawane w drodze wywiadu pogłębionego odpowiadali w czasie wolnym poza godzinami zajęć i poza terenem szkoły. Dobór próby odbywał się metodą kuli śnieżnej, jednakże warunkiem koniecznym był minimalny staż służby wynoszący 3 lata. Badania prowadzono zarówno metodą ilościową (kwestionariusz ankiety), jak i jakościową (wywiady). W niniejszym artykule zaprezentowane zostaną wyłącznie informacje pozyskane w drodze wywiadów pogłębionych. Odpowiedzi udzieliło 66 funkcjonariuszy (w tym 12 pełniących funkcje kierownicze). Respondenci byli zróżnicowani pod względem społeczno-demograficznym.

Analiza zaufania pracowników może dotyczyć wielu płaszczyzn: zaufania między pracownikami, zaufania do przełożonych, zaufania do misji i celu organizacji, zaufania do organizacji jako źródła dochodów i pozycji społecznej, wreszcie zaufania do samego siebie (rozumianego jako świadomość własnych możliwości i kompetencji). W niniejszym artykule zaufanie będzie rozpatrywane przede wszystkim w kontekście relacji między pracownikami. Jak zaprezentowano na Rysunku 1, zaufanie to dotyczy kilku podstawowych czynników: wspólnego celu, wspólnego języka i umiejętności komunikacji, gotowości do podjęcia ryzyka, gotowości i otwartości na współpracę i pracę zespołową oraz uczciwości. Analiza zebranego materiału będzie dokonywana właśnie w oparciu o tych kilka elementów. Stanowią one w dużym stopniu odzwierciedlenie metod i sposobów zarządzania zasobami ludzkimi $\mathrm{w}$ policji, które to zarządzanie skutkuje umiejętnością współpracy opartej na wysokim stopniu zaufania. Zarządzanie w wielu zawodach wysokiego ryzyka dotyczy kreowania klimatu organizacji opartego na kształtowaniu i umacnianiu postaw pracowniczych, które będą ukierunkowane na identyfikowanie się z misją organizacji, budowaniem atmosfery zaufania i współpracy oraz uczciwości zarówno w życiu zawodowym, jak i osobistym. Jest to o tyle istotne, że wszelkie procesy zachodzące $\mathrm{w}$ organizacji są odzwierciedleniem systemu norm i wartości oraz zwyczajów - świadomości zbiorowej (Ściborek 2010, s. 359). Tworzenie odpowiedniego klimatu organizacji jest w dużej mierze uwarunkowane sposobem zarządzania, poziomem zaufania i umiejętnością współpracy.

\section{Wspólny cel - zaufanie do misji organizacji}

Biorąc pod uwagę charakter i podstawę funkcjonowania policji, cel i jej misja wydają się nie budzić żadnych wątpliwości. „Tworzy się Policję jako umundurowaną i uzbrojoną formację służącą społeczeństwu i przeznaczoną do ochrony bezpieczeństwa ludzi oraz do utrzymania bezpieczeństwa i porządku publicznego" 
(Ustawa z dnia 6 kwietnia 1990 r. o Policji). Świadomość znaczenia i misji policji jest najważniejszym wyznacznikiem służby $\mathrm{w}$ tej formacji, stanowi również podstawę zaufania w stosunku do niej. Funkcjonariusze wstępujący w szeregi policji składają ślubowanie, w którym przysięgają wiernie służyć społeczeństwu i ojczyźnie, jednocześnie ufają, że misja, której się podjęli, jest jedyną słuszną. „Wstępując w szeregi policji, musisz zgadzać się z jej misją - nie można jej podważać lub negować. Albo się z nią zgadzasz i utożsamiasz, albo nie ma tu miejsca dla ciebie. Zaufanie do organizacji i współpracowników jest podstawą naszej służby. Służba to nie praca, to powołanie i misja" (mężczyzna 42 lata, 18 lat służby). Policjanci zdają sobie sprawę z misyjnego charakteru ich służby: „Jeśli wybrałeś służbę dlatego, że chciałeś się dorobić, albo zaspokoić jakieś «chore» poczucie władzy, to bardzo szybko stracisz serce do tej roboty. Tutaj tylko chęć niesienia pomocy, zrobienia czegoś dobrego dla innych może zrekompensować trudne warunki pracy, niskie wynagrodzenie, czy nawet brak szacunku ze strony tych, którym chcesz pomóc [...]. Nie można być dobrym policjantem, jeśli nie kocha się tego, co się robi, i jeśli nie rozumie się, po co została powołana ta formacja" (mężczyzna 38 lat, 15 lat służby). Misja, jakiej podejmują się w swojej pracy zawodowej policjanci, jest podstawą wyboru takiej ścieżki zawodowej - mają oni bowiem świadomość, że każde ich działanie będzie miało wpływ na funkcjonowanie całego społeczeństwa, a właściwa realizacja misji stanowi gwarancję ładu i porządku społecznego. „Dla nas - kobiet, podobnie jak dla mężczyzn, ważne jest, by praca przynosiła satysfakcję. A satysfakcję ze służby w policji można osiągnąć tylko wtedy, gdy widzi się znaczenie wykonywanych obowiązków służbowych. Jasne, że większość z nas oprócz bycia policjantką jest również żoną i matką, ale to, co nas odróżnia od pozostałych żon i matek, to znaczenie pracy, jaką na co dzień wykonujemy" (kobieta 43 lata, 18 lat służby). Analiza wypowiedzi respondentów wskazuje, że mają oni całkowitą świadomość misji i celu formacji, do której należą. Jest to również podstawa ich funkcjonowania $\mathrm{w}$ roli pracownika. Wspólny cel i utożsamianie się z misją organizacji/instytucji stanowią podstawę zaufania, które z kolei przekłada się na współpracę mającą zaowocować osiągnięciem wspólnego celu. W przypadku policjantów celem jest zminimalizowanie zagrożeń dla ładu i porządku społecznego, służba i pomoc wszystkim ludziom niezależnie od ich cech społeczno-demograficznych. „Łączy nas wspólny cel, wspólna misja, wszyscy gramy do jednej bramki - ktoś, kto działa wbrew filozofii firmy, nie ma prawa do niej przynależeć" (mężczyzna 37 lat, 12 lat służby).

Utożsamianie się z celem organizacji jest jednym z czynników budujących zaufanie, stanowi również element niezbędny dla współpracy. Dużą rolą przełożonych/zarządzających jest tutaj umiejętność i chęć kształtowania pozytywnych postaw w stosunku do służby. Realizacja zamierzonych celów może i powinna scalać grupę pracowniczą, ponieważ wymaga współpracy. „Zaufanie związane jest z gotowością do dobrowolnej współpracy, a nie pod wpływem przymusu czy zastraszenia" (Sankowska 2011, s. 73). Znajomość misji organizacji i utożsamianie się $\mathrm{z}$ nią jest - w przypadku zawodów wysokiego ryzyka - szczególnie istotne, ponieważ przekłada się w sposób bezpośredni na całość społeczeństwa. 


\section{Wspólny język - komunikacja}

Poprawna komunikacja stanowi istotny warunek efektywnej działalności niezależnie od jej charakteru. W zawodach wysokiego ryzyka mamy do czynienia zarówno z komunikacją pionową, jak i poziomą. Komunikacja pionowa jest ściśle wpisana $\mathrm{w}$ organizację funkcjonowania tzw. grup dyspozycyjnych, do których należy policja. Istnieje hierarchia służbowa, która dotyczy nie tylko procesu zarządzania, ale również komunikacji. Pionowa komunikacja w organizacji dotyczy w głównej mierze przekazywania poleceń służbowych oraz uzyskiwania informacji od pracowników (Krupski 2004, s. 116). W służbie funkcjonariuszy oprócz specyficznej nomenklatury zawodowej istnieje również szereg określeń, które są przynależne właśnie tej grupie zawodowej. Istnienie żargonu policyjnego nie jest czymś nowym, funkcjonuje od lat. Ułatwia on i przyśpiesza komunikację, stanowi również swoiste sito oddzielające „swoich” od „obcych”. Sami funkcjonariusze podkreślają, że jest to element integrujący, zbliżający ich do siebie, swoisty rodzaj więzi, szczególnie w zakresie komunikacji poziomej, ale również pionowej. „W naszym żargonie istnieje bardzo wiele określeń, które dla osób spoza firmy mogą być niejasne, a czasem wręcz głupie. Używamy pewnych skrótów, pewnych zdrobnień z kilku powodów - po pierwsze: ludzie spoza policji nie powinni pewnych rzeczy wiedzieć, po drugie: zamiast mówić pełnym zdaniem «Przestępczość gospodarcza», mówimy po prostu «PG», po trzecie: jest to sposób na zdystansowanie się do pewnych kwestii, swoiste bagatelizowanie ich, by nie obciążać nadto psychiki. Tak, zdecydowanie można powiedzieć, że język jest elementem, który nas integruje i ułatwia współpracę" (34 lata, 8 lat służby). Swoistość języka, który ma zarazem ułatwiać komunikację, jak i integrować, ma również znaczenie dla podejmowanej przez policjantów współpracy. „Celem komunikowania jest poprawa współdziałania, a nie poprawa porozumienia [...]. Intencją współdziałania może być realizacja wspólnego przedsięwzięcia lub celu dla każdego z uczestników procesu komunikowania się, takiego jednak, który wymaga jakiejś formy akcji z drugiej strony" (Żądło 2014, s. 22). Umiejętność efektywnej komunikacji jest podstawą właściwej i owocnej współpracy między uczestnikami danego działania.

\section{Przestrzeganie zasad}

Jasno określone zasady, które zostaną zinternalizowane przez członków danej grupy, warunkują jej istnienie. Dotyczy to wszystkich rodzajów i form tworów społecznych: rodzin, grup koleżeńskich, grup zawodowych, narodów etc. Nie inaczej jest w przypadku funkcjonariuszy policji - tutaj klarowne zasady i konieczność ich przestrzegania stanowią o możliwości istnienia tej formacji. Nie ma tutaj miejsca na dobrowolne interpretowanie przepisów i reguł działania. Istotną rolę pełnią tu przełożeni, którzy mogą i powinni egzekwować respektowanie zasad przez podwładnych. Ich samych również dotyczy ten sam kodeks, co przekłada się na dawanie swoistego przykładu. Przepisy jasno określają działania policjantów w danej sytuacji i muszą się oni do nich dostosować. „Działanie zgodnie z przepisami prawa jest dla nas obowiązkiem. Znajomość i przestrzeganie przepisów gwarantuje, że w określonej sytuacji będziemy wiedzieli, jak należy postąpić. Jedno- 
cześnie daje nam to pewne poczucie pewności, bo przepisy mają charakter ogólny i wszyscy policjanci stosują je jednakowo, więc niezależnie od tego, z kim przyjdzie mi pełnić służbę, to będę miał pewność, że ta osoba postąpi tak jak ja" (mężczyzna 39 lat, 15 lat służby). Istnienie zasad i standardów postępowania sprzyja w sposób oczywisty współpracy między policjantami - wszyscy muszą dostosować się do takiego samego systemu, co skutkuje również większym poziomem integracji wewnątrz grupy. „Osoba, która łamie zasady, nie przestrzega przepisów, nie może być członkiem naszej formacji. Nie wyobrażam sobie służby z kimś, kto stosuje «wolnoamerykankę» - tu nie ma miejsca na takie zachowanie" (kobieta 41 lat, 16 lat służby). Zasady i ich przestrzeganie mają - zdaniem respondentów - znaczenie integrujące, a to w sposób bezpośredni przekłada się na współpracę między nimi.

\section{Gotowość do podjęcia ryzyka}

Gotowość do podjęcia ryzyka dotyczy nie tylko zawodów wysokiego ryzyka. Jest ona istotna w każdej grupie zawodowej, choć w każdej owo ryzyko może być inaczej definiowane. W przypadku policjantów definicja ryzyka jest bardzo prosta i oczywista - dotyczy sytuacji, która może stworzyć zagrożenie dla zdrowia lub życia funkcjonariuszy lub innych członków społeczeństwa. „Ryzyko jest wpisane w nasz zawód. Każdy, kto decyduje się na służbę w policji, musi być świadomy zagrożenia, jakie ze sobą niesie. Oczywiście na kursach uczą nas, by niepotrzebnie nie ryzykować, minimalizować zagrożenie etc., ale moim zdaniem największe poczucie bezpieczeństwa daje sprawdzony partner, który nie zawaha się ryzykować swoim życiem, by mi pomóc. Ja sam nie wahałbym się ani chwili, bo w służbie jesteśmy nie tylko współpracownikami, ale bardzo często najlepszymi przyjaciółmi. Ta praca bardzo zbliża, szczególnie gdy przeżyło się razem jakieś trudne i niebezpieczne akcje" (mężczyzna 46 lat, 24 lata służby). Świadomość, że partner zawodowy pomoże w każdej trudnej sytuacji, wpływa pozytywnie na współpracę między policjantami. Nie oznacza to oczywiście, że nie zdarzają się przypadki niezdrowej rywalizacji, ale w opinii respondentów, mają one charakter marginalny i są uzależnione od charakteru służby. Przełożeni świadomi istniejącego ryzyka w taki sposób zarządzają kadrami (obsadzanie dyżurów, przydzielanie zadań etc.), by zminimalizować ewentualne niebezpieczeństwo dla życia i zdrowia swoich podwładnych.

\section{Uczciwość}

Budowanie współpracy opartej na zaufaniu nie jest możliwe bez świadomości, że partnerzy relacji są wobec siebie uczciwi. Przekonanie o czystych intencjach drugiej strony daje gwarancję otwartości i rzetelności w działaniach. Dotyczy to zarówno uczciwości przełożonych względem podwładnych i odwrotnie, jak i relacji między pracownikami na tym samym szczeblu struktury organizacyjnej. Budowanie relacji opartej na zaufaniu nie jest możliwe w sytuacji, gdy któraś ze stron nie jest uczciwa, gdy jej intencje są podszyte fałszem. „Jeżeli ktoś skłamie raz, ma etykietę kłamcy, natomiast jeżeli ktoś jest cały czas uczciwy, musiałoby się wydarzyć coś wielkiego, aby został tak określony" (Paliszkiewicz 2013, s. 68). W zawo- 
dach zaufania publicznego, do których należy również służba w policji, nie ma miejsca na brak uczciwości, ponieważ rzutuje to na całą formację, a utrata zaufania do policji może nieść ze sobą bardzo poważne konsekwencje. „Tylko uczciwi i chętni do służby powinni być członkami naszej grupy [...]. Owszem, zdarzają się tzw. «czarne owce», ale powinny być one natychmiast eliminowane z naszego środowiska. Nie wyobrażam sobie pracować z kimś, kto na przykład bierze łapówki albo w inny sposób postępuje nieuczciwie. Nie chcę tu wystawiać policjantom laurki, bo nie o to chodzi, ale jeśli pyta pani o moje zdanie, to jest ono jedno - absolutnie nie chciałabym współpracować z takimi ludźmi”" (kobieta 43 lata, 18 lat służby). Uczciwość wydaje się być oczywistym elementem zaufania będącego podstawą współpracy i raczej nie powinno być wątpliwości co do jego znaczenia w efektywnym współdziałaniu.

\section{Gotowość do wspólpracy i pracy zespołowej}

Wszystkie rozważania na temat zaufania i współpracy stają się bezpodstawne w sytuacji, gdy strony relacji nie wykazują chęci i gotowości do wspólnego działania. Praca zespołowa daje pozytywne efekty nie tylko w postaci dobrych wyników organizacji, poprawia ona także relacje między pracownikami (Lundy, Cowling 2000, s. 326). Do współpracy nie można zmusić, bo nie będzie ona przynosiła zamierzonych efektów. Ważne jest jednak uświadamianie znaczenia pracy zespołowej, bowiem w większości przypadków przynosi ona zdecydowanie lepsze efekty aniżeli indywidualne działanie poszczególnych pracowników (Katzenbach, Smith 2001, s. 21). Służba w policji to w zdecydowanej większości, jeśli nie w całości, praca zespołowa. W zespołach - czy mamy tu na myśli grupy patrolowo-interwencyjne, czy też zespoły powołane do rozwiązania jakiegoś problemu funkcjonariusze realizują swoje ustawowe obowiązki. „Pracujemy jako jedna formacja. Nie walczymy o indywidualne wyniki, ale ważne jest dobro całej jednostki i formacji. Myślę, że działając w pojedynkę, można nawet sobie zaszkodzić, bo raczej zespół nie toleruje takich indywidualistów, są postrzegani w kategorii «outsiderów», a to nie jest dobrze widziane" (mężczyzna 33 lata, 8 lat służby). Otwartość na współpracę i pracę zespołową staje się warunkiem niezbędnym dla budowania klimatu zaufania $\mathrm{w}$ organizacji, co będzie się również przekładało na współpracę między członkami tej organizacji. „W takiej robocie, jak nasza, nie mogą mieć miejsca jakieś głupie personalne konflikty czy przepychanki, bo podstawą naszej służby jest wzajemne zaufanie i pewność, że partner w sytuacji zagrożenia pośpieszy nam z pomocą. Jeśli dochodzi do jakichś spięć (bo oczywiście mają one miejsce - to nieuniknione), są one natychmiast rozwiązywane, by nie pozostawiać sytuacji bez wyjaśnienia. Myślę, że między policjantami istnieje bardzo silna solidarność, którą widać szczególnie właśnie w sytuacjach kryzysowych..." (mężczyzna 33 lata, 8 lat służby).

Powyższa analiza czynników wpływających na zaufanie i współpracę w policji wskazuje, że sami zainteresowani są świadomi ich znaczenia. Prawdopodobnie na co dzień nie zastanawiają się nad ich rolą w wykonywaniu obowiązków służbowych. 


\section{Podsumowanie}

Budowanie klimatu zaufania $\mathrm{w}$ organizacji jest warunkiem niezbędnym dla współpracy i efektywnego jej funkcjonowania. Ogromna w tym rola osób zarządzających, które w istotny sposób kreują atmosferę zaufania i współpracy. Policja jako formacja powołana do ochrony porządku i bezpieczeństwa publicznego musi działać w sposób zorganizowany, co możliwe jest wyłącznie w sytuacji ścisłej współpracy wszystkich funkcjonariuszy. Osiągnięcie pożądanego poziomu współdziałania jest efektem zaufania, jakim darzą się wzajemnie szeregowi policjanci i ich przełożeni, oraz wiary w misję i cel ich służby. Utrata zaufania do współpracowników, przełożonych lub utrata wiary w cel działań mogłaby przynieść daleko większe szkody niż wymiar jednostkowy. Konsekwencje takiego stanu rzeczy dotyczyłyby nie tylko pojedynczych funkcjonariuszy, ale całego środowiska zawodowego i społeczeństwa. O zaufaniu i współpracy w zawodach wysokiego ryzyka należy mówić jak o czymś oczywistym, co jest na stałe wpisane w charakterystykę tych profesji. Niniejsze opracowanie dotyczy zaufania i współpracy w ramach środowiska policjantów, ale należy również pamiętać, że o zaufaniu w zawodach wysokiego ryzyka mówi się również w kontekście zaufania, szacunku i prestiżu, jakim ich przedstawicieli darzy społeczeństwo. Zaufanie w tym wymiarze jest zdecydowanie bardziej skomplikowanym zjawiskiem, a w dużym stopniu wpływa na nie zaufanie i współpraca wewnątrz policji. Brak zaufania i współpracy wśród policjantów będzie odbijał się na ich służbie, a to przykłada się na społeczną ocenę całej formacji.

Zaufanie $w$ organizacji jest przedmiotem licznych opracowań i analiz, co świadczy o jego znaczeniu dla klimatu skutecznego działania. Jego wymiar jednostkowy i globalny sprawia, że staje się ono kluczowe w relacjach międzyludzkich. ,[...] zaufanie jest kierowane ku różnym obiektom czy adresatom, inaczej mówiąc «niepewnym działaniom innych ludzi», którzy mogą występować pod wieloma postaciami, a ich działania przejawiają różny stopień złożoności. Pisząc o złożoności działań i relacji, socjolog przyjmuje określenie kręgów zaufania oraz w ślad za Fukuyamą termin «horyzont zaufania» (publicznego). Horyzont zaufania rozciąga się od najbardziej «konkretnych relacji międzyosobowych do bardziej abstrakcyjnego odniesienia wobec obiektów publicznych: struktur, instytucji, organizacji, państwa»" (Żółkowska 2014, s. 209, za: Sztompka 2007, s. 103-104). Budowanie solidnych podstaw dla zaufania wewnątrz i wokół policji winno stanowić cel wszystkich funkcjonariuszy i być przedmiotem ciągłego doskonalenia i poprawy ewentualnych braków lub uchybień. Dla sprawnego funkcjonowania całej formacji zaufanie między policjantami nie jest zadaniem do wykonania, ale celem samym w sobie, który na każdym etapie ich służby będzie skutkował owocną i korzystną dla całego społeczeństwa współpracą. 


\section{Literatura}

1. Adamiec M., Kożusznik B. (2000), Zarządzanie zasobami ludzkimi. Aktor - kreator - inspirator, Akade, Kraków.

2. Armstrong M. (2000), Zarządzanie zasobami ludzkimi, Oficyna Ekonomiczna, Kraków.

3. Babbie E. (2008), Podstawy badań spolecznych, Wydawnictwo Naukowe PWN, Warszawa.

4. Baier A. (1986), Trust and Antitrust, ,Ethics”, Vol. 96, No. 2, s. 231-260.

5. Barber B. (1983), The Logic and Limits of Trust, Rutgers University Press, New Brunswick.

6. Bugdol M. (2006), Wartości organizacyjne. Szkice z teorii organizacji i zarządzania, Wydawnictwo Uniwersytetu Jagiellońskiego, Kraków.

7. Bugdol M. (2010), Wymiary i problemy zarzadzania organizacja oparta na zaufaniu, Wydawnictwo Uniwersytetu Jagiellońskiego, Kraków.

8. Currall S.C., Judge T.A. (1995), Measuring Trust between Organizational Boundary Role Persons, „Organizational Behavior and Human Decision Processes”, Vol. 64, No. 2, s. $151-170$

9. Fukuyama F. (1997), Zaufanie. Kapitat spoleczny a droga do dobrobytu, Wydawnictwo Naukowe PWN, Warszawa-Wrocław.

10. Katzenbach J.R., Smith D.K. (2001), Siła zespołów. Wpływ pracy zespołowej na efektywność organizacji, Oficyna Ekonomiczna, Kraków.

11. Krupski R. (2004), Podstawy organizacji i zarządzania, WWSZiP, Wydawnictwo I-BiS, Wałbrzych-Wrocław.

12. Lubrańska A. (2008), Psychologia pracy. Podstawowe pojęcia i zagadnienia, Difin, Warszawa.

13. Luhmann N. (2007), Systemy społeczne. Zarys ogólnej teorii, Zakład Wydawniczy Nomos, Kraków.

14. Lundy O., Cowling A. (2000), Strategiczne zarządzanie zasobami ludzkimi, Oficyna Ekonomiczna, Kraków.

15. Mika B. (2009), Sieć zaufania. Jak dzięki zaufaniu niektórzy internetowi kupcy zarabiaja więcej od konkurencji, Europejskie Centrum Edukacyjne, Łysomnice.

16. Milian L. (2002), Praca, osobowość, kierowanie. Wybrane zagadnienia dla studiujacych kierunek zarzadzanie, Wydawnictwo Politechniki Częstochowskiej, Częstochowa.

17. Misztal B. (1977), Zagadnienia społecznego uczestnictwa $i$ współdziałania, Zakład Narodowy im. Ossolińskich, Wrocław.

18. Paliszkiewicz J. (2013), Zaufanie w zarzadzaniu, Wydawnictwo Naukowe PWN, Warszawa.

19. Peszko A. (2002), Podstawy zarządzania organizacjami, Wydawnictwo AGH, Kraków.

20. Rudzewicz A. (2016), Zaufanie w przedsiębiorstwie. Uwarunkowania - relacje - pomiar, Wydawnictwo Uniwersytetu Warmińsko-Mazurskiego w Olsztynie, Olsztyn.

21. Sankowska A. (2011), Wphyw zaufania na zarzadzanie przedsiębiorstwem, Difin, Warszawa.

22. Sztompka P. (2007), Zaufanie. Fundament społeczeństwa, Społeczny Instytut Wydawniczy Znak, Kraków.

23. Ściborek Z. (2010), Zarzadzanie zasobami ludzkimi, Difin, Warszawa.

24. Tittenbrun J. (2006), Własność sity roboczej a kapitał ludzki i kapitał społeczny, [w:] Stępień J. (red.), Praca i kapitał społeczny w procesie budowy społeczeństwa obywatelskiego, Drukarnia „Prodruk”, Poznań, s. 76-89.

25. Ustawa z dnia 6 kwietnia 1990 r. o Policji (Dz.U. 1990 nr 30 poz. 179), rozdział I art. 1.1.

26. Żądło K. (2014), O wartości zaufania. Komunikacja i budowa zaufania a rynkowa wartość przedsiębiorstwa, Poltext, Warszawa.

27. Żółkowska T. (2014), Zaufanie. Szkice teoretyczne, Wydawnictwo Naukowe PWN, Warszawa. 


\title{
MANAGEMENT BASED ON COOPERATION AND TRUST. AN ANALYSIS ON THE EXAMPLE OF THE POLICE PROFESSION
}

\begin{abstract}
Police service belongs to the so-called high-risk professions, and its performance requires adjusting to specific working conditions. The difficulty of professional duties and their significance for the functioning of society requires good cooperation and trust between police officers. This trust concerns not only co-workers but also superiors and the mission of the entire formation. The aim of this article is to present and analyse the results of a study conducted among police officers. The study concerned, among others, the importance of trust and cooperation in carrying out their professional duties. The basis of this study is information obtained through interviews with police officers from all over Poland.
\end{abstract}

Keywords: Police, cooperation, human resources management, trust, high-risk profession 